\title{
Profiling ribonucleotide and deoxyribonucleotide pools perturbed by remdesivir in human bronchial epithelial cells
}

\author{
Yan Li 1, $\ddagger$, Huixia Zhang ${ }^{1, \ddagger}$, Wendi Luo ${ }^{1}$, Christopher Wai Kei Lam ${ }^{2}$, Caiyun Wang ${ }^{1}$, \\ Liping Bai ${ }^{1}$, Vincent Kam Wai Wong ${ }^{1}$, Wei Zhang ${ }^{1, *}$ and Zhihong Jiang ${ }^{1, *}$ \\ 1 State Key Laboratory of Quality Research in Chinese Medicines, Macau Institute for Applied Research in \\ Medicine and Health, Macau University of Science and Technology, Taipa, Macau, China; Guangdong- \\ Hong Kong-Macao Joint Laboratory of Respiratory Infectious Disease (Macau University of Science and \\ Technology) \\ 2 Faculty of Medicine, Macau University of Science and Technology, Taipa, Macau, China; Guangdong- \\ Hong Kong-Macao Joint Laboratory of Respiratory Infectious Disease (Macau University of Science and \\ Technology) \\ $\ddagger$ These authors contributed equally to this work. \\ * Corresponding authors. E-mail addresses: wzhang@must.edu.mo (W. Zhang), Zhjiang@must.edu.mo (Z. \\ Jiang).
}

\begin{abstract}
Remdesivir (RDV) has garnered much hope for its moderate anti-COVID-19 effects, but its limited amelioration of survival in hospitalized patient causes a huge controversy over the applicability of RDV to COVID-19 treatment. Developing strategies to improve its antivirus efficacy is urgently required. As anticipated, RDV exhibits similar behavior with other nucleotide analogs to disrupt the metabolism of natural endogenous ribonucleotides (RNs) and deoxyribonucleotides (dRNs). Alterations in endogenous RNs and dRNs play a critical role in virus replication as well as other key cellular functions. Thus elucidation of the disturbances of RDV on RNs and dRNs could help to understand its exact mechanism of action. Here, the metabolic profiling determined by liquid chromatography-mass spectrometry method showed a general increase in the abundance of nucleotides and a more than 2-fold increase for specific nucleotides. However, the variation of pyrimidine ribonucleotides was relative slight or even contrary, resulting in obvious imbalance between purine and pyrimidine ribonucleotides, which implied the obstacle of RDV to pyrimidine synthesis and could further block the transcription and replication of viral RNA. Additionally, the extreme disequilibrium between cytidine triphosphate (CTP) and cytidine monophosphate might result from the inhibition of CTP synthase and provide a metabolic target for the treatment of COVID-19 infection. Since nucleotides metabolism pathways are vulnerable to nucleotide analogues and are liable to be the regulation targets, it is promising to enhance the efficacy of RDV through co-administration with CTP synthase inhibitors or de novo pyrimidine synthesis inhibitors to exacerbate the imbalance of nucleotide pools.
\end{abstract}

Keywords: remdesivir, perturbation of nucleotide pools, inhibition of RNA and DNA synthesis, CTP synthase.

\section{Introduction}

Remdesivir (RDV), an adenine nucleotide analog that inserts into viral RNA chains resulting in their premature termination [1], has shown a broad-spectrum of antiviral activity against severe acute respiratory syndrome coronavirus (SARS-CoV) [2], Nipah virus [3], Middle East respiratory syndrome coronavirus (MERS-CoV) [4, 5], Ebola virus [6-8] and 2019 novel coronavirus (COVID-19) [9-11]. Because of the advantage of RDV in terms of shortening the time to recovery in adults infected 
with COVID-19, the US Food and Drug Administration issued an Emergency Use Authorization for use of remdesivir for the treatment of hospitalized patients with COVID-19 [12]. Based on previous studies, RDV exerts its antivirus activity through specifically inhibiting the activity of viral RdRps, which are crucial to virus survival not only through replication but also as engines of genome variability and evolution, without interference with human RNA polymerase [13, 14].

The success of application of metabolic reprogramming to treat cancer [15] and inflammation [16] prompted us to explore the possibility to exploit it in RDV treatment. RDV shares similar characteristics with other nucleotide analogs, both of which undergo intracellular phosphorylation to their triphosphate metabolites $[17,18]$. The phosphate prodrug of RDV contributes to bypass the rate-limiting step during translating the parent nucleoside into its monophosphate, and the further esterification and amidation decrease the polarity of phosphorylated nucleoside and increase its permeability $[19,20]$. Although evidences showed that the predominant metabolites RDV in vivo and in vitro were parent nucleoside and RDV-MP, respectively [21, 22], the bioconversion of RDV-MP to RDV-DP and RDV-TP were mediated by the same kinases involved in natural nucleotides synthesis. Due to metabolic competition with natural nucleotides such as AMP, ADP and ATP, RDV inevitably results in perturbation of endogenous RNs, which could restrict the synthesis of viral RNA in turn $[23,24]$. However, to date it remains uncertain to what extent the treatment of RDV in cell results in changes of nucleotide levels.

Besides alteration of adenine nucleotides, RDV might change the levels of other nucleotides via affecting the enzymes in nucleotide synthesis and metabolism. Previous studies have proven that guanine analogs, ribavirin and 5-ethynyl-1-beta-D-ribofuranosylimidazole-4-carboxamide (EICAR) depleted the GTP pool through inhibition of inosinate dehydrogenase $[25,26]$. Similarly, RDV as an adenine analog was deduced to inhibit the S-adenosylhomocysteine (SAH) hydrolase and adenylate kinase, consequently interfering with the biosynthesis of adenine derivatives [27, 28]. Moreover, Kim et al have reported previously that SARS coronavirus may require more ATP to promote stable helicase translocation necessary for delicate RNA replication [29]. Endogenous RNs and dRNs pools also affect the response of RDV against viral infection because the disturbance of adenine derivatives will affect the function of RdRPs [30]. Furthermore, unbalanced change of dRNs caused by RDV could induce potential side effects because failure to maintain the dNTPs level causing genetic abnormalities or cell death [31]. This has already been proven that adaptive metabolic reprogramming of RNs and dRNs pools could promote chemotherapy at the early stage of treatment [32]. Thus elucidation of the disturbances of RDV treatment on RNs and dRNs pool sizes will not only permit us to understand the exact mechanism of action of RDV, but also enhance the antivirus activity based on the targeted-regulation of RNs and dRNs.

So far, there has been no report on the effects of RDV on RNs and dRNs pool sizes due mainly to the difficulty of quantifying these pool sizes, particularly for the monophosphate and diphosphate nucleotides. Recently, we describe a simpler, selective and highly sensitive HPLC-MS/MS method for quantification of RNs and dRNs pools in cells after trimethylsilyl diazomethane (TMSD) derivatization [33]. In the present study, the effects of RDV incubation over different time-periods on RNs and dRNs pool sizes of BEAS-2B cells have been investigated using well-established HPLCMS/MS methodology. Moreover, the influence of RDV on cell cycle, RNA and DNA synthesis and protein expression were studied. The results obtained from this study should facilitate understanding the exact mechanism of RDV and assessment of the efficacy and toxicity of RDV for developing the individualized therapy.

\section{Results}

\section{1. $R D V$ decreased the viability of BEAS-2B cell line}

At the beginning of this study, we investigated the cytotoxicity of RDV on BEAS-2B cells by using MTT assays. The cells were treated with RDV at various concentrations $(0-100 \mu \mathrm{M})$ for 24,48 and $72 \mathrm{~h}$, respectively. As shown in the results, cell number was gradually decreased as the concentration of RDV increased in all the time points of incubation. The viability of cells presented a 
dose- and time- dependent reduces (Figure $1 \mathrm{~A}$ ). The calculated IC 50 values in 48 and $72 \mathrm{~h}$ were 25.3 \pm 2.6 and $9.6 \pm 0.7 \mu \mathrm{M}$, respectively. $10 \mu \mathrm{M}$ was chose for the following experiments.

A
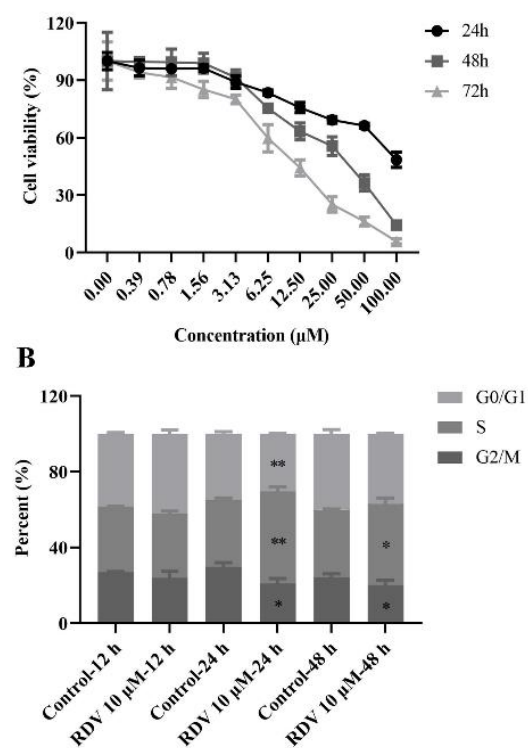

C
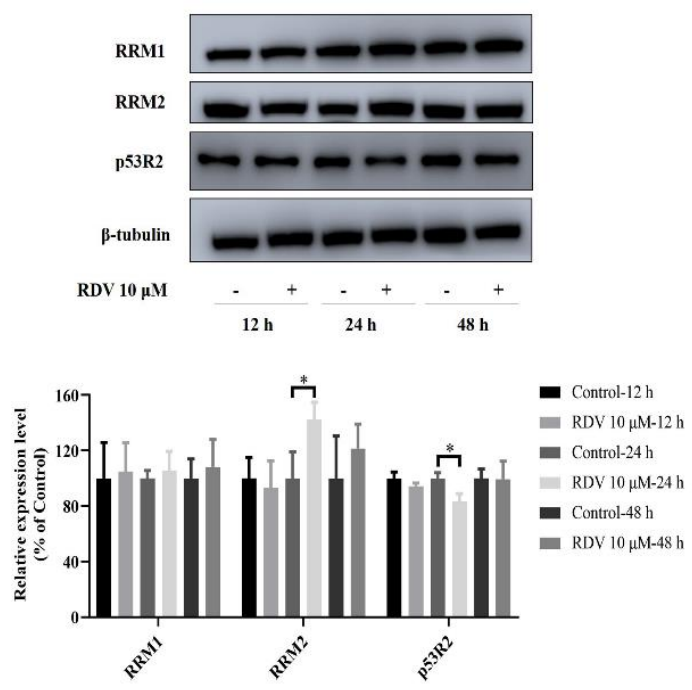

Figure 1. Effects of RDV on (A) cell viability, (B) cell cycle and (C) riboreductase expression in BEAS2B cells treated with $10 \mu \mathrm{M}$ RDV. ( $*: P<0.05, * *: P<0.01$, compared with control group).

\section{2. $R D V$ induced $S$ phase arrest in $B E A S-2 B$ cells}

On account of the significant inhibitory effect on cell viability and proliferation, we investigated the effect of RDV treatment on the distribution of cells in cell cycle under different time point. BEAS$2 B$ cells were treated with or without $10 \mu \mathrm{M}$ RDV for 12,24 and $48 \mathrm{~h}$, and subsequently analyzed by flow-cytometry. As shown in Figure 1 B, an altered pattern of cell cycle was observed in BEAS-2B cells exposed to $10 \mu \mathrm{M} \mathrm{RDV}$ and with respect to control. With the incubation time increased, the proportion of cells in S phase significantly increased while the percentage of cells in G2/M phases obviously decreased in comparison to untreated cells. After incubated for $24 \mathrm{~h}$, the percentage of cells in S phase was $35.3 \pm 0.75 \%$ in control, which gradually increases to $48.69 \pm 1.8 \%$ in RDV group $(P<$ 0.01 ). The number of cell in G2 phase decreased from control $29.67 \pm 1.59 \%$ to $20.81 \pm 1.92 \%$ of RDV $(P<0.05)$. The resembled results at $48 \mathrm{~h}$ was obtained. In brief, RDV can arrest the cells in S phase.

\section{3. $R D V$ inhibited $R N A$ and $D N A$ synthesis}

In order to detect the effects of RDV on RNA and DNA synthesis in proliferating cells, we performed EU and EdU staining method on the basis of click chemistry. EU and EdU are the structural analogues of uridine and deoxyuridine, respectively. Their triphosphate metabolites compete with UTP and TTP to incorporate into newly synthesized RNA and DNA, respectively, and subsequently reacted with Azide -modified fluorophores. The fluorescence intensity was proportional to the amount of the incorporated EU and EdU in nascent RNA and DNA. As shown in Figure $2 \mathrm{~A}$ and B, after incubation with RDV for $14 \mathrm{~h}$, the fluorescence intensity of Alexa594-azide decreased significantly in comparison to control group, indicating the reduction of RNA and DNA synthesis, and the inhibition of proliferation of BEAS-2B cells. Interestingly, not all DAPI stained cells were labeled with EdU. The reason for this phenomenon is that the incorporation of EdU only occurs in S phase during DNA replicating, while DAPI is a nonspecific fluorescent dye with the strong binding ability to the existing or nascent DNA [37]. 
A

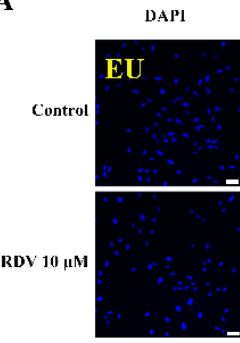

C
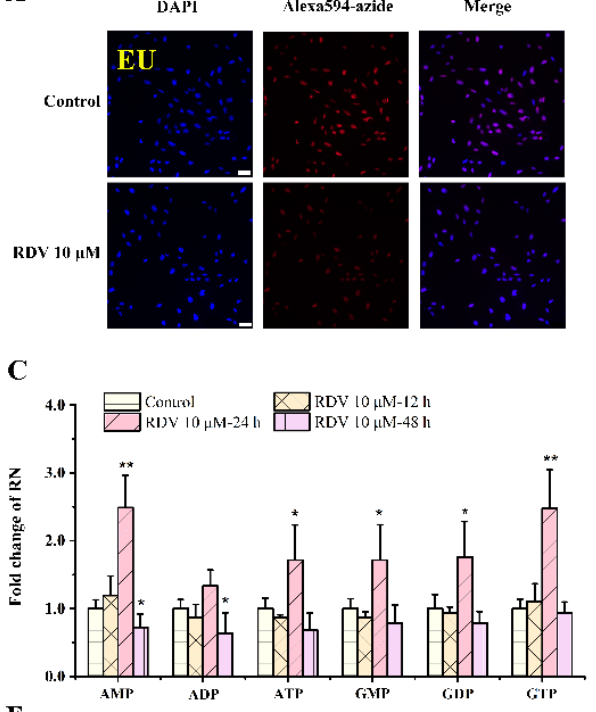

$\mathbf{E}$

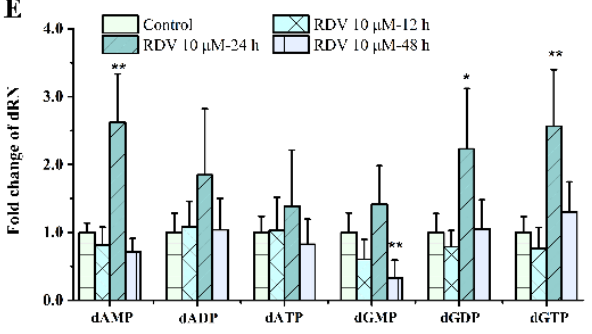

B

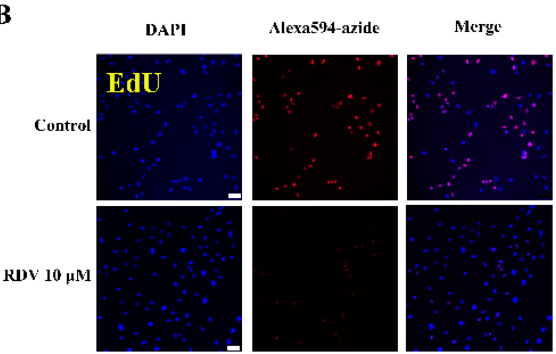

D
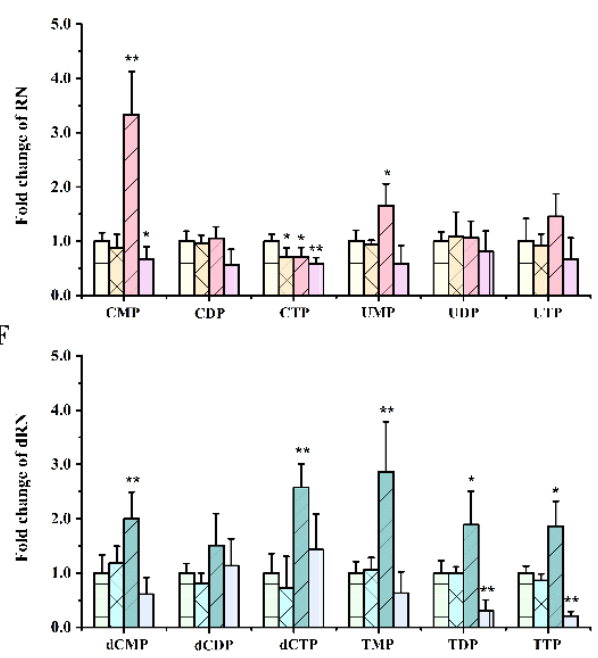

Figure 2. Effects of RDV on the RNA and DNA synthesis (A-B), and on the nucleotide pools (C-F). Fluorescence microscope images (Scale Bars $=100 \mu \mathrm{m}$ ) of EU or EdU-mediated click chemistry indicated that RDV treatment for $14 \mathrm{~h}$ inhibited the synthesis of (A) RNA and (B) DNA. Fold changes in nucleotide abundances, as measured by LC/MS-MS, in $10 \mu \mathrm{M}$ RDV-treated or vehicle-treated BEAS-2B cells for 12, 24 and 48 hours (C-F). ( $*: P<0.05, * *: P<0.01$, compared with control group).

\subsection{Perturbation of $R N$ s and $d R N$ s pool size by $R D V$ in $B E A S-2 B$ cells}

To examine metabolic reprogramming events that influence the cellular response to virus, we used targeted LC/MS-MS via selected reaction monitoring (SRM) to examine changes in the steadystate metabolomics profile of BEAS-2B cells after exposure to $10 \mu \mathrm{M}$ RDV with $12 \mathrm{~h}, 24 \mathrm{~h}$ and $48 \mathrm{~h}$. The specific nucleotide levels were shown in Supplementary Table 1 and Table 2 . The fold change of the nucleotides were evaluated by comparison of their concentrations in cells treated with RDV and in the parallel controlled RDV-free cells at the same time points. Significant differences in the metabolite profiles of cells with or without RDV were observed. In general, RDV increased the abundance of the majority of RN and $\mathrm{dRN}$ species after $24 \mathrm{~h}$ incubation, including a greater than 2fold increase in AMP, GTP, dAMP, dGDP, dGTP, dCTP and TMP levels, then decreased to the normal levels at $48 \mathrm{~h}$ (Figure $2 \mathrm{C}-\mathrm{F}$ ). A rational interpretation was that RDV significantly inhibited the synthesis of nascent RNA and DNA, and arrested the cell cycle in S phase, inevitably resulting in the accumulation of (deoxy)nucleoside triphosphates and subsequently the increase of their respective di- and monophosphates [38]. However, it was notable that most of the pyrimidine ribonucleotides remained unchanged or even declined, among which the significant decrease of CTP was in stark contrast to the 3 -fold greater increment of CMP after incubation for $24 \mathrm{~h}$ (Figure $2 \mathrm{D}$ ). CTP is synthesized from UTP by CTP synthase, which is the rate-limiting step of de novo CTP biosynthesis and probably a practical target just as in the treatment of leukemia [39] and parasitic infections [4042]. In this study, the ratio of CTP/UTP was calculated and shown a significant decrease after 24 incubation (Figure $3 \mathrm{D}$ ), implying the inhibition effect of RDV on CTP synthase. Besides of the de novo pathway, the salvage pathway plays an important role in cellular nucleotides metabolism as well. 
The relative low level of CTP might allosterically activate the recycle of free bases and nucleosides to promote the production of CMP, resulting in the abnormal elevation of CMP (Figure 4).

A

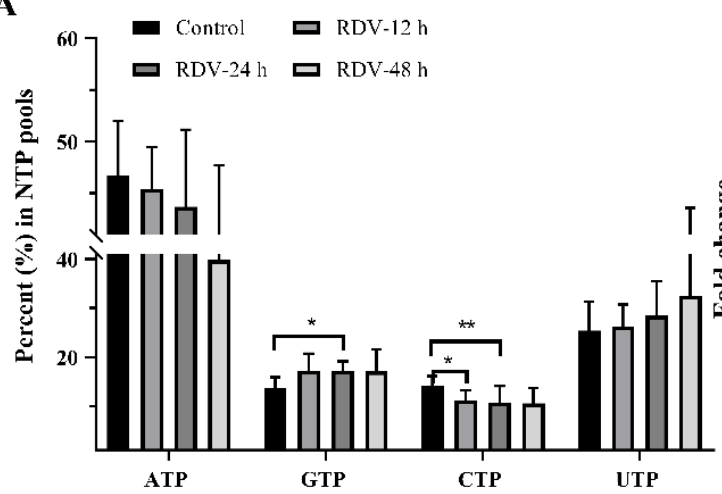

B

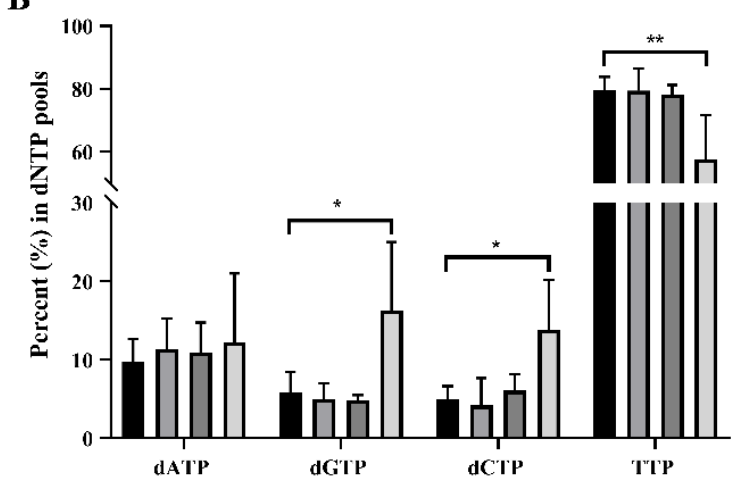

C

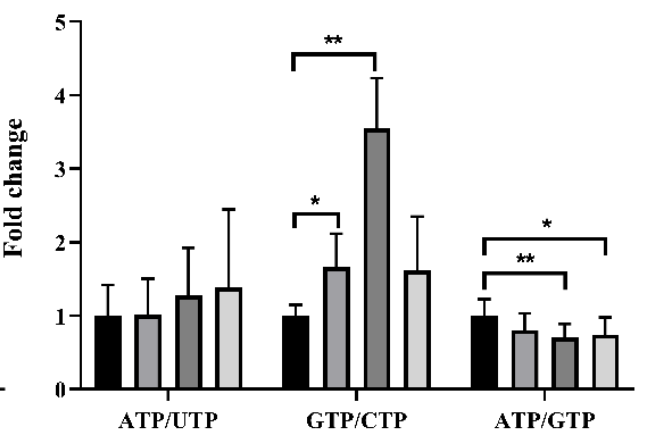

D

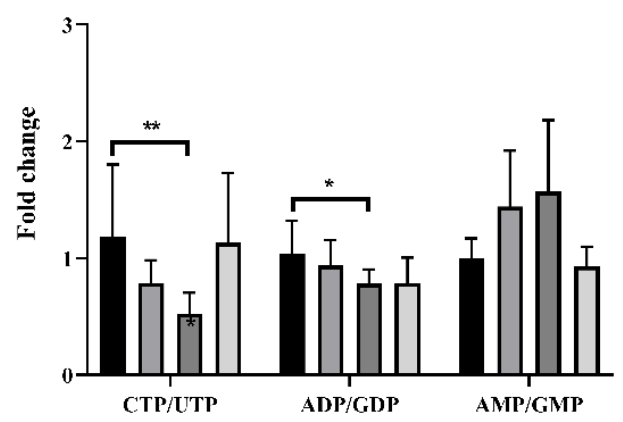

Figure 3. RDV exposure $(10 \mu \mathrm{M})$ perturbed the balance of (A) NTPs and (B) dNTPs, and altered the relative ratios of specific nucleotides (C and D).

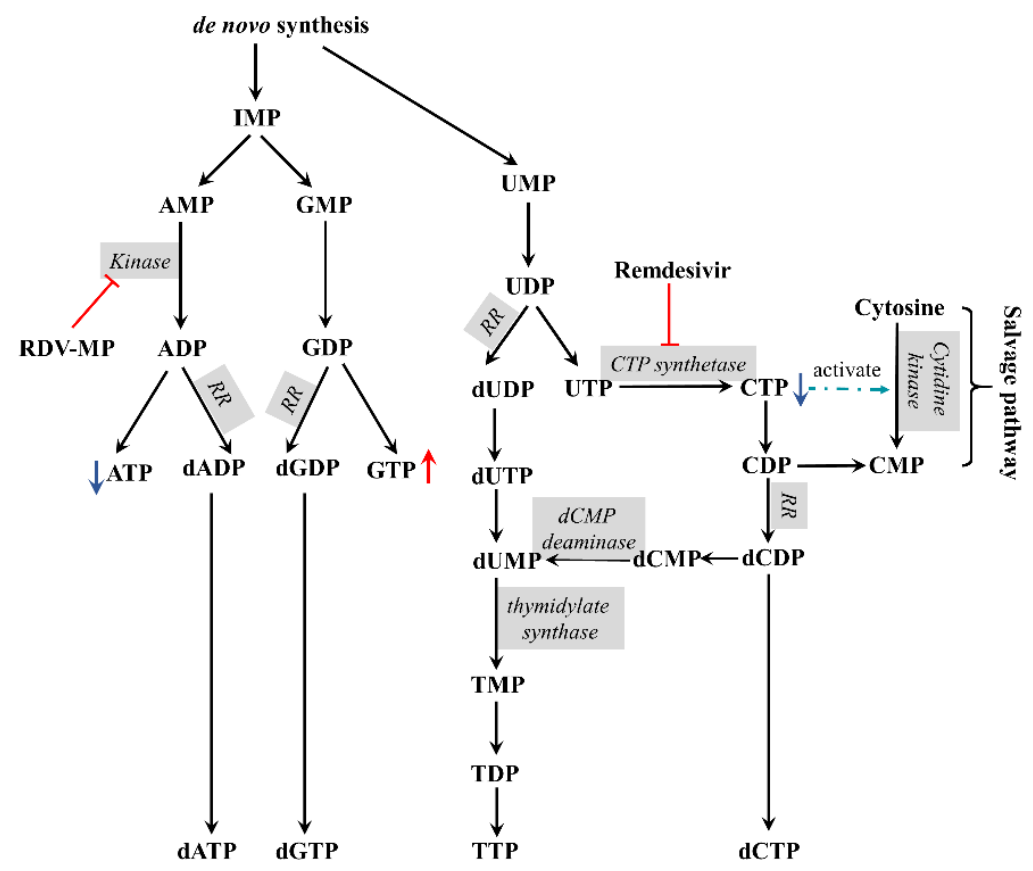

Figure 4. Effect of remdesivir on de novo and salvage pathways of nucleotides synthesis.

The alterations in nucleotide pools were also evaluated through comparing the percent of each NTP in the whole nucleotide pools. It showed that RDV exposure $(10 \mu \mathrm{M})$ stimulates an increase in GTP and a decrease in CTP (Figure 3 A). Consequently, a significant increment of GTP/CTP was observed (Figure $3 \mathrm{C}$ ), indicating the huge disequilibrium in $\mathrm{RN}$ pools. Although there were no 
statistically significant differences, the level of ATP reduced and UTP increased slightly (Figure 3A), resulting in the elevated ratio of ATP/UTP (Figure $3 \mathrm{C}$ ). From the aspect of drug disposition, RDV was hydrolyzed to its corresponding nucleoside monophosphate (RDV-MP) in cell, and furtherly metabolized to RDV-TP. Due to the structural similarity of RDV-MP to AMP, the further phosphorylation of RDV-MP was achieved through the competitive inhibition of adenylate kinase, which inevitably resulted in the accumulation of AMP and the decrease of ADP and ATP. Meanwhile, the accumulation of AMP might inhibited the activity of adenylosuccinate synthase and the whole purine biosynthesis pathway in a negative feedback mode, which would simultaneously decrease the production of GMP, and ultimately GDP and GTP[43]. This speculation was proved by the relative high levels of the AMP/GMP ratio and the reduced ATP/GTP and ADP/GDP ratios at $24 \mathrm{~h}$ and $48 \mathrm{~h}$ (Figure $3 \mathrm{C}$ and D). The relative percent of dNTPs pools were shown in Figure $3 \mathrm{~B}$. The change of dNTPs percent were just contrary to that of NTPs, and there was obvious hysteresis, which was probably because of the allosteric regulation of NTPs to riboreductase. In summary, RDV exerted the antiviral activity partly via aggravating the imbalance of nucleotide pools, especially through reducing CTP.

\section{5. $R D V$ upregulated the riboreductase $R 2$ expression}

The remarkably evaluated dNTP pools in cell are probably related with the dNTP synthesis enzymes, especially the ribonucleotide reductase (RR) that catalyzes the formation of deoxyribonucleotides from ribonucleotides [44, 45]. Mammalian RR is comprised of three subunits including RRM1, RRM2 and p53R2, which are expressed in a cell cycle-dependent manner [46]. In cycling cells, the RRM1 protein is metabolically stable throughout the cell cycle whereas the expression and degradation of RRM2 protein limit the S-phase-dependent activity of RR complex, leading to the high cellular dNTPs pools at $S$ phase and low dNTPs pools outside $S$ phase [47]. To further investigated whether the growth inhibitory activity of RDV resulted from the induction of RR, we determined the expression of RRM1, RRM2 and p53R2 by using western blot assay. From the results (Figure $1 \mathrm{C}$ ), there' no obvious difference of RRM1 level after the BEAS-2B cells incubated with RDV for 12, 24 and $48 \mathrm{~h}$. However, the expression of RRM2 was significantly increased after 24 $\mathrm{h}$ exposure to RDV at $10 \mu \mathrm{M}(\mathrm{P}<0.05)$, which caused by the $\mathrm{S}$ phase arrest. At the same time, the p53R2 level presented distinct down-regulated tendency $(\mathrm{P}<0.05)$. In addition, there were also no changes in the levels of RRM2 and p53R2 after $48 \mathrm{~h}$ incubation with RDV. Taken together, it suggested that RDV inhibited the proliferation of BEAS-2B cells through the impact on RR expression.

\section{Discussion}

Although authorized for COVID-19 treatment, RDV still cannot meet the clinical needs due to the unsatisfied therapeutic outcome and high mortality [11]. It is therefore urgent to develop new treatment modalities with high efficacy, among which co-administration is a practical strategy. For this purpose, we investigated and found that RDV arrested BEAS-2B cells in the $S$ phase, remarkably inhibited the biosynthesis of nascent RNA and DNA, perturbed RNs and dRNs pool size, and upregulated the expression of riboreductase. Further, based on the action mechanism of RDV, we tried to develop several substances to enhance RDV's antiviral efficacy via a combined strategy. As shown in this study, the RDV-induced decrease of CTP level probably represented a metabolic target for the treatment of COVID-19. The main source of CTP is from the conversion of UTP to CTP by CTP synthase in pyrimidine biosynthesis. Based on the biological property of CTP synthase, coadministration of remdesivir with cyclopentenyl cytosine, an analogue of CTP [48], would be an effective means of sensitizing human bronchial epithelium cells against virus infection. Another helpful strategy might be combination treatment with remdesivir and leflunomide, a clinically approved inhibitor of the de novo pyrimidine synthesis pathway, to reduce the CTP production as realized in the reversion of drug resistance of triple-negative breast cancer (TNBC) [32].

\section{Materials and Methods}




\subsection{Reagents and chemicals}

3-(4,5-dimethylthiazol-2-yl)-2,5-diphenyltetrazolium bromide (MTT), dimethyl sulfoxide (DMSO), paraformaldehyde (PFA), propidium iodide (PI), $0.05 \%$ RNase A were provided by SigmaAldrich Inc. (St. Louis, MO, USA). RDV was purchased from Manhey Chemical Limited (Hong Kong, China). For our experiments, the stock solution of RDV was prepared in DMSO, stored at $-20{ }^{\circ} \mathrm{C}$ and serially diluted in Dulbecco's Modified Eagle's Medium (DMEM) until needed. The final DMSO concentration did not exceed $0.1 \%$ throughout this study. 5-ethynyl uridine (EU) and 5-ethynyl-2'deoxyuridine (EdU) were supplied by Tokyo Chemical Industry Co., Ltd. (Shanghai, China). 4', 6Diamidino-2-phenylindole (DAPI) and Alexa Fluor ${ }^{\mathrm{TM}} 594$ were purchased from Invitrogen Co. (Carlsbad, CA, USA). Glycine, Tris, $\mathrm{CuSO}_{4}$, ascorbic acid, EDTA, Triton ${ }^{\mathrm{TM}} \mathrm{X}-100$ and TWEEN ${ }^{\circledR 2} 20$ were also obtained from Sigma-Aldrich Inc. RIPA buffer (Cell Signaling Technologies Inc. Beverly, MA, USA), Bradford reagent (Bio-Rad Laboratory, Hercules, CA, USA), nitrocellulose membrane (Merck Millipore, USA) and the enhanced chemiluminescence reagents (Invitrogen, Paisley, Scotland, UK) were also used in this study. For cell culture, DMEM, fetal bovine serum (FBS), penicillinstreptomycin solution, phosphate Buffer Saline (PBS) and $0.25 \%$ Trypsin-EDTA solution were obtained from GIBCO (Grand Island, NY, USA).

The stable isotope labeled adenosine- ${ }^{13} \mathrm{C}_{10},{ }^{15} \mathrm{~N} 5$-triphosphate (ATP- ${ }^{13} \mathrm{C}_{10},{ }^{15} \mathrm{~N}_{5}$ ) and adenosine${ }^{13} \mathrm{C}_{10},{ }_{15} \mathrm{~N}_{5}$-monophosphate (AMP-13 $\mathrm{C}_{10},{ }^{15} \mathrm{~N}_{5}$ ), other nucleotide standards and ammonium acetate $\left(\mathrm{NH}_{4} \mathrm{OAc}\right)$ were purchased from Sigma-Aldrich Inc. (St. Louis, MO, USA). TMSD and tetrafluoroboric acid (HBF4) were obtained from Alfa Aesar Co. (Ward Hill, MA, USA). The methanol (LC-MS grade) and acetonitrile used for the LC-MS/MS analysis were bought from Anaqua Chemical Supply (Houston, TX, USA). Formic acid was bought from Fisher Scientific Co. (Fair Lawn, NJ, USA) and diethyl ether was obtained from Tedia Co. (Fairfield, OH, USA) while acetic acid (AcOH) and $30 \%$ ammonium hydroxide aqueous solution $\left(\mathrm{NH}_{4} \mathrm{OH}\right)$ were purchased from J. T. Baker Chemical Co. (Phillipsburg, NJ, USA). The solid phase extraction (SPE) cartridges (WAX, $3 \mathrm{~cm}^{3} ; 30 \mathrm{mg}, 60 \mu \mathrm{m}$ ) was bought from Waters Co. (Milford, MA, USA) while the chromatographic column Sepax GP-C 18 $(2.1 \times 150 \mathrm{~mm} 2,1.8 \mu \mathrm{m})$ from Sepax Technologies (Newark, DE, USA) was also used. Ultrapure water was obtained on the basis of a Milli-Q Gradient water system (Millipore, Bedford, MA, USA).

\subsection{Cell culture and colorimetric MTT assay}

BEAS-2B cells were purchased from the ATCC (Manassas, VA, United States). They were cultured in DMEM supplemented with 10\% FBS, $100 \mathrm{U} / \mathrm{mL}$ penicillin-streptomycin in a humidified incubator at $37^{\circ} \mathrm{C}$ and $5 \% \mathrm{CO}_{2}$. Cell viability was determined by a modified colorimetric MTT assay [34]. Briefly, the logarithmic BEAS-2B cells at $6.0 \times 10^{4}$ cells $/ \mathrm{mL}$ were seeded in a 96 -well plate at 100 $\mu \mathrm{L} /$ well for $24 \mathrm{~h}$ at $37^{\circ} \mathrm{C}$, then treated with RDV at different concentrations $(0-100 \mu \mathrm{M})$ for 24,48 and $72 \mathrm{~h}$, respectively. After the appropriate incubation time, $10 \mu \mathrm{L}$ MTT solution $(5 \mathrm{mg} / \mathrm{mL})$ was added for another $4 \mathrm{~h}$ incubation, and $100 \mu \mathrm{L}$ DMSO was added to dissolve formazan crystals for the further measurement at $570 \mathrm{~nm}$ using a microplate ultraviolet-visible spectrophotometer. Cell viability was calculated as follows: cell viability $(\%)=$ (absorbance of the test group/absorbance of the control group) $\times 100$. The IC 50 value was taken as the concentration that caused $50 \%$ inhibition of cell viability and was calculated by GraphPad Prism. (Graph-Pad Software, Inc., La Jolla, CA, USA).

\subsection{EU and EdU detection using click chemistry}

In order to label and visualize specifically newly synthesized DNA and RNA, the click chemistry method was used. The experiments were conducted based on previous publications with slight modification [35, 36]. In short, BEAS-2B cells were grown in 6-well plate at $2.0 \times 10^{5}$ cells/well for 24 $\mathrm{h}$ and then incubated for $14 \mathrm{~h}$ with $1.0 \mathrm{mM}$ EU or $10 \mu \mathrm{M}$ EdU in the presence or absence of $10 \mu \mathrm{M}$ RDV. After the labeling, cells were washed with PBS and fixed with $4 \%$ PFA for $30 \mathrm{~min}$. The fixed cells were neutralized with $2 \mathrm{mg} / \mathrm{mL}$ glycine, rinsed with PBS and stained for $30 \mathrm{~min}$ at room temperature with a click reaction buffer including $100 \mathrm{mM}$ Tris, $1 \mathrm{mM} \mathrm{CuSO} 4,10 \mu \mathrm{M}$ Alexa594-azide and $100 \mathrm{mM}$ ascorbic acid. After staining, cells were washed several times by using PBS with $0.5 \mathrm{mM}$ 
EDTA, $1 \%$ TWEEN ${ }^{\circledR 2} 20$ and $0.1 \%$ Triton ${ }^{\text {TM }} \mathrm{X}-100$, and then stained with $0.5 \mu \mathrm{g} / \mathrm{mL}$ DAPI for $30 \mathrm{~min}$. Finally, the cells were imaged by IncuCyte ZOOM Live-Cell Analysis Platform.

\subsection{Cell cycle analysis}

BEAS-2B cells were seeded in 6-plate at $2.0 \times 10^{5}$ cells/well, cultured for $24 \mathrm{~h}$ and then treated with/without RDV for 12, 24 and $48 \mathrm{~h}$, respectively. Then, the cells were harvested, re-suspended in ice-cold PBS and fixed with $70 \%$ ethanol at $-20{ }^{\circ} \mathrm{C}$ overnight. Subsequently, the fixed cells were washed again using ice-cold PBS and incubated with $500 \mu \mathrm{L}$ PI containing $0.05 \%$ RNase A for $30 \mathrm{~min}$ at room temperature in the dark circumstances. Finally, cell cycle distribution profile after the staining treatment was accessed by flow cytometry. The percentages of cells in G0/G1, S and G2/M phases were analyzed by using MODFIT software (Verity Sofware House, USA).

\subsection{Western blot assay}

BEAS-2B cells were treated with RDV at the indicated concentration for 12,24 and $48 \mathrm{~h}$, respectively. Then the cells were washed with cold PBS twice and lysed with RIPA buffer on ice. The lysates were centrifuged at $12000 \mathrm{~g}$ for $30 \mathrm{~min}$ at $4{ }^{\circ} \mathrm{C}$ in order to acquire the protein samples. The concentration of cellular total protein was measured by using the Bradford reagent at $595 \mathrm{~nm}$ according to the manufacturer's instructions. $30 \mu \mathrm{g}$ protein samples were loaded on $10 \%$ SDS-PAGE gel and transferred to onto nitrocellulose membranes. The membranes were blocked with $5 \%$ skim milk for $1.5 \mathrm{~h}$, followed by the incubation of primary antibodies diluted in Tris-buffered saline with Tween ${ }^{\circledR} 20$ (TBST) buffer. (1:1000 for $\beta$-tubulin, RRM1, RRM2 and P53R2, Cell Signaling Technologies, Danvers, MA) overnight at $4{ }^{\circ} \mathrm{C}$. After that, the membranes were washed with TBST and incubated with secondary horseradish peroxidase-conjugated antibody anti-rabbit IgG (Cell Signaling Technologies, Inc. Danvers, MA, USA) for $1 \mathrm{~h}$ at room temperature. The immunoreactive protein bands were finally detected with an Amersham Imager 600 Western blotting system. Densitometry analysis of protein band was performed by Quantity One software (Version 4.6.2, BioRad, USA).

\subsection{Sample preparation and LC-MS/MS analysis}

BEAS-2B cells were plated in $10 \mathrm{~cm}$ petri dishes with the density of $2.0 \times 10^{6} \mathrm{cells} /$ dish, cultured with medium for $24 \mathrm{~h}$ and then treated with RDV for 12, 24 and $48 \mathrm{~h}$, respectively. After that, the cells were re-suspended with ice-cold PBS. The number of cells was counted before centrifugation at 1200 rpm for $5 \mathrm{~min}$, and the cell pellet was washed with $1.0 \mathrm{~mL}$ ice-cold PBS again and spun down at 1200 rpm for $5 \mathrm{~min}$. Subsequently cell pellets were treated with $150 \mu \mathrm{L} 80 \%$ methanol containing $4 \mu \mathrm{M}$ AMP-13 $\mathrm{C}_{10},{ }^{15} \mathrm{~N}_{5}$ and $2 \mu \mathrm{M}$ ATP- ${ }^{13} \mathrm{C}_{10},{ }^{15} \mathrm{~N}_{5}$ as an internal standards (IS). The following sample preparation and the determination of endogenous RNs and dRNs were performed based on the method previously described [33]. The concentrations of cellular nucleotides were finally calculated according to dividing the absolute amount of each $\mathrm{RN}$ and $\mathrm{dRN}$ in each sample by the corresponding cell number.

\subsection{Statistics analysis}

Data analyses were performed using GraphPad Prism software and the values were expressed as mean \pm standard deviation (SD) from three independent replicate experiments. The statistical significance of the comparison between control and treated groups was determined by Student's ttest or one-way ANOVA, which is indicated as ${ }^{*} P<0.05$ and ${ }^{* *} P<0.01$.

Supplementary Materials: Supplementary materials can be found at www.mdpi.com/xxx/s1.

Author Contributions: Conceptualization, W.Z, Y.L. and H.Z.; methodology, W.Z, Y.L. and H.Z.; software, W.L; validation, Y.L., H.Z.; formal analysis, C.W.; investigation, W.Z, H.Z. L.B.; resources, W.Z, Z.J. and V.K.W.W.; data curation, Y.L., H.Z.; writing-original draft preparation, H.Z. and Y.L.; writing-review and editing, 
C.W.K.L., W.Z., and V.K.W.W.; visualization, C.W.; project administration, W.Z. and Z.J.; funding acquisition, W.Z.. All authors have read and agreed to the published version of the manuscript.

Funding: This research was funded by the Science and Technology Development Fund, Macau SAR (File no. 0033/2020/A and 0023/2019/AKP).

Acknowledgments: The authors also thank the Department of Science and Technology of Guangdong Province for the support of Guangdong-Hong Kong-Macao Joint Laboratory of Respiratory Infectious Disease.

Conflicts of Interest: The authors declare no conflict of interest.

\section{Abbreviations}

\begin{tabular}{|c|c|}
\hline RDV & Remdesivir \\
\hline COVID-19 & 2019 novel coronavirus \\
\hline RNA & Ribonucleic acid \\
\hline DNA & Deoxyribonucleic acid \\
\hline RdRps & RNA-dependent RNA polymerases \\
\hline RDV-MP & Remdesivir nucleoside monophosphate \\
\hline RDV-DP & Remdesivir nucleoside diphosphate \\
\hline RDV-TP & Remdesivir nucleoside triphosphate \\
\hline RNs & Ribonucleotides \\
\hline dRNs & Deoxyribonucleotides \\
\hline NTPs & Ribonucleoside triphosphates \\
\hline dNTPs & Deoxyribonucleoside triphosphates \\
\hline AMP & Adenosine monophosphate \\
\hline GMP & Guanosine monophosphate \\
\hline IMP & Inosine monophosphate \\
\hline UMP & Uridine monophosphate \\
\hline $\mathrm{CMP}$ & Cytidine monophosphate \\
\hline ADP & Adenosine diphosphate \\
\hline GDP & Guanosine diphosphate \\
\hline UDP & Uridine diphosphate \\
\hline CDP & Cytidine diphosphate \\
\hline ATP & Adenosine triphosphate \\
\hline GTP & Guanosine triphosphate \\
\hline СТP & Cytidine triphosphate \\
\hline dAMP & Deoxyadenosine monophosphate \\
\hline dGMP & Deoxyguanosine monophosphate \\
\hline dUMP & Deoxyuridine monophosphate \\
\hline TMP & Thymidine monophosphate \\
\hline $\mathrm{dCMP}$ & Deoxycytidine monophosphate \\
\hline $\mathrm{dADP}$ & Deoxyadenosine diphosphate \\
\hline dGDP & Deoxyguanosine diphosphate; \\
\hline dUDP & Deoxyuridine diphosphate \\
\hline TDP & Thymidine diphosphate \\
\hline $\mathrm{dCDP}$ & Deoxycytidine diphosphate \\
\hline dATP & Deoxyadenosine triphosphate \\
\hline dGTP & Deoxyguanosine triphosphate \\
\hline dUTP & Deoxyuridine triphosphate \\
\hline TTP & Thymidine triphosphate \\
\hline dCTP & Deoxycytidine triphosphate \\
\hline HPLC-MS/MS & High-performance liquid chromatography- tandem mass spectrometry \\
\hline
\end{tabular}

\section{References}

1. Warren, T.K.; Jordan, R.; Lo, M.K.; Ray, A.S.; Mackman, R.L.; Soloveva, V.; Siegel, D.; Perron, M.; 
Bannister, R.; Hui, H.C.; Larson, N.; Strickley, R.; Wells, J.; Stuthman, K.S.; Van Tongeren, S.A.; Garza, N.L.; Donnelly, G.; Shurtleff, A.C.; Retterer, C.J.; Gharaibeh, D.; Zamani, R.; Kenny, T.; Eaton, B.P.; Grimes, E.; Welch, L.S.; Gomba, L.; Wilhelmsen, C.L.; Nichols, D.K.; Nuss, J.E.; Nagle, E.R.; Kugelman, J.R.; Palacios, G.; Doerffler, E.; Neville, S.; Carra, E.; Clarke, M.O.; Zhang, L.; Lew, W.; Ross, B.; Wang, Q.; Chun, K.; Wolfe, L.; Babusis, D.; Park, Y.; Stray, K.M.; Trancheva, I.; Feng, J.Y.; Barauskas, O.; Xu, Y.; Wong, P.; Braun, M.R.; Flint, M.; McMullan, L.K.; Chen, S.S.; Fearns, R.; Swaminathan, S.; Mayers, D.L.; Spiropoulou, C.F.; Lee, W.A.; Nichol, S.T.; Cihlar, T.; Bavari, S. Therapeutic efficacy of the small molecule GS-5734 against Ebola virus in rhesus monkeys. Nature 2016, 531, (7594), 381-385, doi: 10.1038 /nature17180.

2. Sheahan, T.P.; Sims, A.C.; Graham, R.L.; Menachery, V.D.; Gralinski, L.E.; Case, J.B.; Leist, S.R.; Pyrc, K.; Feng, J.Y.; Trantcheva, I.; Bannister, R.; Park, Y.; Babusis, D.; Clarke, M.O.; Mackman, R.L.; Spahn, J.E.; Palmiotti, C.A.; Siegel, D.; Ray, A.S.; Cihlar, T.; .. Baric, R.S.. Broad-spectrum antiviral GS-5734 inhibits both epidemic and zoonotic coronaviruses. Sci. Transl. Med. 2017, 9, (396), eaal3653, doi: 10.1126/scitranslmed.aal3653.

3. Lo, M.K.; Feldmann, F.; Gary, J.M.; Jordan, R.; Bannister, R.; Cronin, J.; Patel, N.R.; Klena, J.D.; Nichol, S.T.; Cihlar, T.; Zaki, S.R.; Feldmann, H.; Spiropoulou, C.F.; de Wit, E.. Remdesivir (GS-5734) protects African green monkeys from Nipah virus challenge. Sci. Transl. Med. 2019, 11, (494), eaau9242, doi: 10.1126/scitranslmed.aau9242.

4. Sheahan, T.P.; Sims, A.C.; Leist, S.R.; Schafer, A.; Won, J.; Brown, A.J.; Montgomery, S.A.; Hogg, A.; Babusis, D.; Clarke, M.O.; Spahn, J.E.; Bauer, L.; Sellers, S.; Porter, D.; Feng, J.Y.; Cihlar, T.; Jordan, R.; Denison, M.R.; Baric, R.S. Comparative therapeutic efficacy of remdesivir and combination lopinavir, ritonavir, and interferon beta against MERS-CoV. Nat. Commun. 2020, 11, (1), 1-14, doi: 10.1038/s41467019-13940-6.

5. de Wit, E.; Feldmann, F.; Cronin, J.; Jordan, R.; Okumura, A.; Thomas, T.; Scott, D., Cihlar, T.; Feldmann, H.. Prophylactic and therapeutic remdesivir (GS-5734) treatment in the rhesus macaque model of MERSCoV infection. PNAS 2020, 117, (12), 6771-6776, doi: 10.1073/pnas.1922083117.

6. Jacobs, M.; Rodger, A.; Bell, D.J.; Bhagani, S.; Cropley, I.; Filipe, A.; Gifford, R.J.; Hopkins, S.; Hughes, J.; Jabeen, F.; Johannessen, I.; Karageorgopoulos, D.; Lackenby, A.; Lester, R.; Liu, R.S.; MacConnachie, A.; Mahungu, T.; Martin, D.; Marshall, N.; Mepham, S.; Orton, R.; Palmarini, M.; Patel, M.; Perry, C.; Peters, S.E.; Porter, D.; Ritchie, D.; Ritchie, N.D.; Seaton, R.A.; Sreenu, V.B.; Templeton, K.; Warren, S.; Wilkie, G.S.; Zambon, M.; Gopal, R.; Thomson, E.C.. Late Ebola virus relapse causing meningoencephalitis: a case report. The Lancet 2016, 388, (10043), 498-503, doi: 10.1016/S01406736(16)30386-5.

7. Dornemann, J.; Burzio, C.; Ronsse, A.; Sprecher, A.; De Clerck, H.; Van Herp, M.; Kolie, M.C.; Yosifiva, V.; Caluwaerts, S.; McElroy, A.K.; Antierens, A. First Newborn Baby to Receive Experimental Therapies Survives Ebola Virus Disease. J. Infect. Dis. 2017, 215, (2), 171-174, doi: 10.1093/infdis/jiw493.

8. Mulangu, S.; Dodd, L.E.; Davey, R.T. Jr.; Tshiani Mbaya, O.; Proschan, M.; Mukadi, D.; Lusakibanza Manzo, M.; Nzolo, D.; Tshomba Oloma, A.; Ibanda, A.; Ali, R.; Coulibaly, S.; Levine, A.C.; Grais, R.; Diaz, J.; Lane, H.C.; Muyembe-Tamfum, J.J.; PALM Writing Group; Sivahera, B.; Camara, M.; Kojan, R.; Walker, R.; Dighero-Kemp, B.; Cao H.; Mukumbayi, P.; Mbala-Kingebeni, P.; Ahuka, S.; Albert, S.; Bonnett, T.; Crozier, I.; Duvenhage, M.; Proffitt, C.; Teitelbaum, M.; Moench, T.; Aboulhab, J.; Barrett, K.; Cahill, K.; Cone, K.; Eckes, R.; Hensley, L.; Herpin, B.; Higgs, E.; Ledgerwood, J.; Pierson, J.; Smolskis, M.; Sow, Y.; Tierney, J.; Sivapalasingam, S.; Holman, W.; Gettinger, N.; Vallée, D.; Nordwall, 
J.; PALM Consortium Study Team. A Randomized, Controlled Trial of Ebola Virus Disease Therapeutics. N. Engl. J. Med. 2019, 381, (24), 2293-2303, doi: 10.1056/NEJMoa1910993.

9. Holshue, M.L.; DeBolt, C.; Lindquist, S.; Lofy, K.H.; Wiesman, J.; Bruce, H.; Spitters, C.; Ericson, K.; Wilkerson, S.; Tural, A.; Diaz, G.; Cohn, A.; Fox, L.; Patel, A.; Gerber, S. I.; Kim, L.; Tong, S.; Lu, X.; Lindstrom, S.; Pallansch, M.A.; Weldon, W.C.; Biggs, H.M.; Uyeki, T.M.; Pillai, S.K.; Washington State 2019-nCoV Case Investigation Team. First Case of 2019 Novel Coronavirus in the United States. N. Engl. J. Med. 2020, 382, (10), 929-936, doi: 10.1056/NEJMoa2001191.

10. Wang, M., Cao, R., Zhang, L., Yang, X., Liu, J., Xu, M., Shi, Z., Hu, Z., Zhong, W., Xiao, G.. Remdesivir and chloroquine effectively inhibit the recently emerged novel coronavirus (2019-nCoV) in vitro. Cell Res. 2020, 30, (3), 269-271, doi: 10.1038/s41422-020-0282-0.

11. Beigel, J.H.; Tomashek, K.M.; Dodd, L.E.; Mehta, A.K.; Zingman, B.S.; Kalil, A.C.; Hohmann, E.; Chu, H.Y.; Luetkemeyer, A.; Kline, S.; Lopez de Castilla, D.; Finberg, R.W.; Dierberg, K.; Tapson, V.; Hsieh, L.; Patterson, T.F.; Paredes, R.; Sweeney, D.A.; Short, W.R.; Touloumi, G.; Lye, D.C.; Ohmagari, N.; Oh, M.D.; Ruiz-Palacios, G.M.; Benfield, T.; Fatkenheuer, G.; Kortepeter, M.G.; Atmar, R.L.; Creech, C.B.; Lundgren, J.; Babiker, A.G.; Pett, S.; Neaton, J.D.; Burgess, T.H.; Bonnett, T.; Green, M.; Makowski, M.; Osinusi, A.; Nayak, S.; Lane, H.C.; Members, A.-S.G. Remdesivir for the Treatment of Covid-19 Preliminary Report. N. Engl. J. Med. 2020, doi: 10.1056/NEJMoa2007764.

12. US Food and Drug Administration. Administration, U. F. D. Authorization for emergency use of remdesivir for the treatment of COVID-19 (letter). https:/www.fda.gov/media/137564/download. May 1, 2020 .

13. Tchesnokov, E.P.; Feng, J.Y.; Porter, D.P.; Gotte, M. Mechanism of Inhibition of Ebola Virus RNADependent RNA Polymerase by Remdesivir. Viruses 2019, 11, (4), 326-341, doi: 10.3390/v11040326.

14. Ju, J.; Li, X.; Kumar, S.; Jockusch, S.; Chien, M.; Tao, C.; Morozova, I.; Kalachikov, S.; Kirchdoerfer, R.N.; Russo, J.J. Nucleotide Analogues as Inhibitors of SARS-CoV Polymerase. bioRxiv 2020, March 14, doi: $10.1101 / 2020.03 .12 .989186$.

15. Luengo, A.; Gui, D.Y.; Vander Heiden, M.G. Targeting Metabolism for Cancer Therapy. Cell Chem. Biol. 2017, 24, (9), 1161-1180, doi: 10.1016/j.chembiol.2017.08.028.

16. Ip, W.E.; Hoshi, N.; Shouval, D.S.; Snapper, S.; Medzhitov, R.. Anti-inflammatory effect of IL-10 mediated by metabolic reprogramming of macrophages. Science 2017, 356, (6337), 513-519, doi: $10.1126 /$ science.aal3535.

17. Lee, W.A.; He, G.X.; Eisenberg, E.; Cihlar, T.; Swaminathan, S.; Mulato, A.; Cundy, K.C. Selective intracellular activation of a novel prodrug of the human immunodeficiency virus reverse transcriptase inhibitor tenofovir leads to preferential distribution and accumulation in lymphatic tissue. Antimicrob. Agents Chemother. 2005, 49, (5), 1898-906, doi: 10.1128/AAC.49.5.1898-1906.2005.

18. Ray, A.S.; Fordyce, M.W.; Hitchcock, M.J. Tenofovir alafenamide: A novel prodrug of tenofovir for the treatment of Human Immunodeficiency Virus. Antiviral. Res. 2016, 125, 63-70, doi: 10.1016/j.antiviral.2015.11.009.

19. Siegel, D.; Hui, H.C.; Doerffler, E.; Clarke, M.O.; Chun, K.; Zhang, L.; Neville, S.; Carra, E.; Lew, W.; Ross, B.; Wang, Q.; Wolfe, L.; Jordan, R.; Soloveva, V.; Knox, J.; Perry, J.; Perron, M.; Stray, K.M.; Barauskas, O.; Feng, J.Y.; Xu, Y.; Lee, G.; Rheingold, A.L.; Ray, A.S.; Bannister, R.; Strickley, R.; Swaminathan, S.; Lee, W.A.; Bavari, S.; Cihlar, T.; Lo, M.K.; Warren, T.K.; Mackman, R.L. Discovery and Synthesis of a Phosphoramidate Prodrug of a Pyrrolo[2,1-f][triazin-4-amino] Adenine C-Nucleoside (GS-5734) for the Treatment of Ebola and Emerging Viruses. J. Med. Chem. 2017, 60, (5), 1648-1661, 
doi: 10.1021/acs.jmedchem.6b01594.

20. Cho, A.; Saunders, O.L.; Butler, T.; Zhang, L.; Xu, J.; Vela, J.E.; Feng, J.Y.; Ray, A.S.; Kim, C.U. Synthesis and antiviral activity of a series of 1'-substituted 4-aza-7,9-dideazaadenosine C-nucleosides. Bioorg. Med. Chem. Lett. 2012, 22, (8), 2705-7, doi: 10.1016/j.bmcl.2012.02.105.

21. Williamson, B.N.; Feldmann, F.; Schwarz, B.; Meade-White, K.; Porter, D.P.; Schulz, J.; van Doremalen, N.; Leighton, I.; Yinda, C.K.; Perez-Perez, L.; Okumura, A.; Lovaglio, J.; Hanley, P.W.; Saturday, G.; Bosio, C.M.; Anzick, S.; Barbian, K.; Cihlar, T.; Martens, C.; Scott, D.P.; Munster, V.J.; de Wit, E.. Clinical benefit of remdesivir in rhesus macaques infected with SARS-CoV-2. Nature 2020, 1-6, doi: 10.1038/s41586-020-2423-5.

22. Yan, V.C.; Muller, F.L.. Advantages of the Parent Nucleoside GS-441524 over Remdesivir for Covid-19 Treatment. ACS. Med. Chem. Lett. 2020, 11, (7), 1361-1366, doi: 10.1021/acsmedchemlett.0c00316.

23. Boccardo G.; Accotto, G.P.. RNA-Dependent RNA Polymerase Activity in Two Morphologically Different White Clover Cryptic Viruses. Virology 1988, 163, (2), 413-419, doi: 10.1016/0042-6822(88)90282-6.

24. Fahima T., Kazmierczak P., Hansen D.R., Pfeiffer P., Van Alfen N.K.. Membrane-Associated Replication of an Unencapsidated Double-Strand RNA of the Fungus, Cryphonectria parasitica. Virology 1993, 195, (1), 81-89, doi: 10.1006/viro.1993.1348.

25. Stridh, S.. Determination of Ribonneleoside Triphosphate Pools in Influenza A Virus-Infected MDCK Cells. Arch. Virol 1983, 77, (2-4), 223-229, doi: 10.1007/BF01309269.

26. Balzarini J., Karlsson A., Wang L., Bohman C., Horská K., Votruba I., Fridland A., Van Aerschot A., Herdewijn P., De Clercq E.. Eicar (5-ethynyl-1-beta-D-ribofuranosylimidazole-4-carboxamide). A novel potent inhibitor of inosinate dehydrogenase activity and guanylate biosynthesis. The Journal of Biological Chemistry 1993, 268, (33), 24591-24598.

27. De Clercq, E.. New Nucleoside Analogues for the Treatment of Hemorrhagic Fever Virus Infections. Chem Asian J 2019, 14, (22), 3962-3968, doi: 10.1002/asia.201900841.

28. Bistulfi, G.; Diegelman, P.; Foster, B.A.; Kramer, D.L.; Porter, C.W.; Smiraglia, D.J. Polyamine biosynthesis impacts cellular folate requirements necessary to maintain S-adenosylmethionine and nucleotide pools. FASEB J. 2009, 23, (9), 2888-97, doi: 10.1096/fj.09-130708.

29. Jang, K.J.; Jeong, S.; Kang, D.Y.; Sp, N.; Yang, Y.M.; Kim, D.E. A high ATP concentration enhances the cooperative translocation of the SARS coronavirus helicase nsP13 in the unwinding of duplex RNA. Sci. Rep. 2020, 10, (1), 4481-4493, doi: 10.1038/s41598-020-61432-1.

30. Vander Heiden M.G.; DeBerardinis, R.J.. Understanding the Intersections between Metabolism and Cancer Biology. Cell 2017, 168, (4), 657-669, doi: 10.1016/j.cell.2016.12.039.

31. Mathews, C.K. Deoxyribonucleotides as genetic and metabolic regulators. FASEB J. 2014, 28, (9), 383240, doi: 10.1096/fj.14-251249.

32. Brown, K.K.; Spinelli, J.B.; Asara, J.M.; Toker, A. Adaptive Reprogramming of De Novo Pyrimidine Synthesis Is a Metabolic Vulnerability in Triple-Negative Breast Cancer. Cancer Discov. 2017, 7, (4), 391 399, doi: 10.1158/2159-8290.CD-16-0611.

33. Li, Z.; Zhang, H.X.; Li, Y.; Lam, C.W.K.; Wang, C.Y.; Zhang, W.J.; Wong, V.K.W.; Pang, S.S.; Yao, M.C.; Zhang, W.. Method for Quantification of Ribonucleotides and Deoxyribonucleotides in Human Cells Using (Trimethylsilyl)diazomethane Derivatization Followed by Liquid Chromatography-Tandem Mass Spectrometry. Anal. Chem. 2019, 91, (1), 1019-1026, doi: 10.1021/acs.analchem.8b04281.

34. van Meerloo, J.; Kaspers, G.J.; Cloos, J. Cell sensitivity assays: the MTT assay. Methods Mol. Biol. 2011, 731, 237-45, doi: 10.1007/978-1-61779-080-5_20. 
35. Jao, C.Y.; Salic, A.. Exploring RNA transcription and turnover in vivo by using click chemistry. Proc. Natl. Acad. Sci. USA. 2008, 105, (41), 15779-84, doi: 10.1073/pnas.0808480105.

36. Akbalik, G.; Langebeck-Jensen, K.; Tushev, G.; Sambandan, S.; Rinne, J.; Epstein, I.; Cajigas, I.; Vlatkovic, I.; Schuman, E.M. Visualization of newly synthesized neuronal RNA in vitro and in vivo using click-chemistry. RNA Biol. 2017, 14, (1), 20-28, doi: 10.1080/15476286.2016.1251541.

37. Qu, D.; Wang, G.; Wang, Z.; Zhou, L.; Chi, W.; Cong, S.; Ren, X.; Liang, P.; Zhang, B. 5-Ethynyl-2'deoxycytidine as a new agent for DNA labeling: detection of proliferating cells. Anal. Biochem. 2011, 417, (1), 112-121, doi: 10.1016/j.ab.2011.05.037.

38. Du, L.; Yang, F.; Fang, H.; Sun, H.; Chen, Y.; Xu, Y.; Li, H.; Zheng, L.; Zhou, B.S. AICAr suppresses cell proliferation by inducing NTP and dNTP pool imbalances in acute lymphoblastic leukemia cells. FASEB J. 2019, 33, (3), 4525-4537, doi: 10.1096/fj.201801559RR.

39. Verschuur, A.; Van Gennip, A.; Muller, E.; Voute, P.; Van Kuilenburg, A.. Increased Activity of Cytidinetriphosphate Synthetase in Pediatric Acute Lymphoblastic Leukemia. In Purine and pyrimidine metabolism in man IX, Springer: 1998; pp 667-671.

40. Fijolek, A.; Hofer, A.; Thelander, L. Expression, purification, characterization, and in vivo targeting of trypanosome CTP synthetase for treatment of African sleeping sickness. J. Biol. Chem. 2007, 282, (16), 11858-11865, doi: 10.1074/jbc.M611580200.

41. Hofer, A.; Steverding, D.; Chabes, A.; Brun, R.; Thelander, L.. Trypanosoma brucei CTP synthetase: a target for the treatment of African sleeping sickness. Proceedings of the National Academy of Sciences 2001, 98, (11), 6412-6416, doi: 10.1073/pnas.111139498.

42. Tamborini, L.; Pinto, A.; Smith, T.K.; Major, L.L.; Iannuzzi, M.C.; Cosconati, S.; Marinelli, L.; Novellino, E.; Presti, L.L.; Wong, P.E.. Synthesis and biological evaluation of CTP synthetase inhibitors as potential agents for the treatment of African trypanosomiasis. ChemMedChem 2012, 7, (9), 1623-1634, doi: 10.1002/cmdc.201200304.

43. Nelson, D.L.; Lehninger A.L.; Cox, M.M.. Lehninger principles of biochemistry (4th ed.). 2008.862 p.

44. Liu, B.; Grosshans, J.. The role of dNTP metabolites in control of the embryonic cell cycle. Cell Cycle 2019, 18, (21), 2817-2827, doi: 10.1080/15384101.2019.1665948.

45. Mathews, C.K. DNA precursor metabolism and genomic stability. FASEB J. 2006, 20, (9), 1300-14, doi: 10.1096/fj.06-5730rev.

46. Yousefi, B.; Samadi, N.; Ahmadi, Y.. Akt and p53R2, partners that dictate the progression and invasiveness of cancer. DNA Repair (Amst) 2014, 22, 24-9, doi: 10.1016/j.dnarep.2014.07.001.

47. Engström Y.; Eriksson S.; Jildevik I.; Skog S.; Thelander, L.; Tribukait, B.. Cell cycle-dependent expression of mammalian ribonucleotide reductase. Differential regulation of the two subunits. J. Biol. Chem. 1985, 260, 9114-9116.

48. Kang, G.J.; Cooney, D.A.; Moyer, J.D.; Kelley, J.A.; Kim, H.Y.; Marquez, V.E.; Johns, D.G.. Cyclopentenylcytosine triphosphate. Formation and inhibition of CTP synthetase. J. Biol. Chem. 1989, 264, (2), 713-718. 